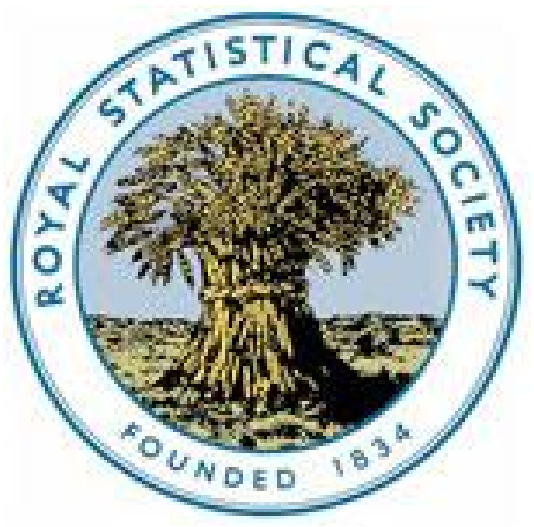

\title{
WILEY
}

\section{Roumania's Forty Years' Progress, 1866-1906}

\section{Author(s): Leon Gaster}

Source: Journal of the Royal Statistical Society, Vol. 70, No. 1 (Mar., 1907), pp. 122-129

Published by: Wiley for the Royal Statistical Society

Stable URL: http://www.jstor.org/stable/2339506

Accessed: 25-06-2016 20:08 UTC

Your use of the JSTOR archive indicates your acceptance of the Terms \& Conditions of Use, available at

http://about.jstor.org/terms

JSTOR is a not-for-profit service that helps scholars, researchers, and students discover, use, and build upon a wide range of content in a trusted digital archive. We use information technology and tools to increase productivity and facilitate new forms of scholarship. For more information about JSTOR, please contact support@jstor.org.

Royal Statistical Society, Wiley are collaborating with JSTOR to digitize, preserve and extend access to Journal of the Royal Statistical Society 


\section{IV.-Roumania's Forty Years' Progress, 1866-1906. By Leon Gaster.}

ThE present area of Roumania is about $\mathrm{I} 30, \mathrm{I} 77$ square kilometres, and from the climatological point of view it is one of the countries which has extreme temperatures well pronounced. In the summer the heat rises to $35^{\circ}$ Centigrade $\left(95^{\circ} \mathrm{F}\right.$.), and exceptionally to $40^{\circ}$ $\left(104^{\circ} \mathrm{F}\right.$.). In the winter it falls to $25^{\circ}$ below zero $\left(-13^{\circ} \mathrm{F}\right.$.), and in exceptional cases even as low as $30^{\circ}\left(-22^{\circ}\right.$ F.). The winters are long and cold, but as a rule abundant in snow. The spring is short, and subject to occasional frosts ; the summers are warm, and often very dry, the pleasantest season being the autumn. The physico-chemical composition of the Roumanian soil is very suitable for pasture and agricultural pursuits, the north of Moldavia being more fertile than that of Muntenia.

Population.-The population of Roumania in December, 1899, at the last census, was about $5,956,900$ inhabitants, but it is now estimated to exceed $6,500,000$. The average excess of births over deaths is about $\mathbf{I} \cdot 2$ per cent., and under ordinary circumstances it is expected that the population may be doubled in about sixtyfive years. The number of inhabitants per square kilometre of inhabitable area is estimated at 50 . The urban population of Roumania is estimated to exceed $r, 250,000$. The principal towns are: Bucharest, with over 300,000 inhabitants ; Iassy, with 79,000; Galatzi, with 65,000 ; Braila, with 59,000, \&c., and the rest, of $5,250,000$, form the rural population.

The principal occupation is agriculture, in which about 60 per cent. are employed; about ro per cent. are engaged in the manufacturing industries, about 5 per cent. in commerce, about 7 per cent. are Government employees and pensioners, and the rest are represented by the liberal professions and the people without any occupation. The arable area over which agricultural pursuits has been extended exceeded, in the year 1905, r5,500,000 acres; and, adding to this the area of the forests and gardens, it approaches 76 per cent. of the whole area of the country.

Among the cereals grown, wheat and maize have the most prominent places. In 1905 , wheat was sown over an area extending 5,000,000 acres, with an average yield of a little over 7 hectolitres per acre (a hectolitre $=2$ bushels 3.35 pecks). In the last forty years the area over which wheat was sown has increased by 150 per cent., and the yield by $46 \mathrm{I}$ per cent. The export of wheat in 1866 was about 238,360 tons, representing a value of $2,200,000 l$.; in 1905 the export exceeded I,7 I6,000 tons, valued at 10,043,000l. The area on which maize was grown in 1905 exceeded $5,000,000$ acres; the average production, however, hâs fallen considerably during the last few years. Amongst other cereals of importance grown in the country are oats, barley, rye, \&c. The total export of cereals in 1866 amounted to 547,608 tons, and in the year 1905 it exceeded 2,650,000 tons.

In 1905 , the vineyards extended over an.area of 225,000 acres, from which over $1,800,000$ hectolitres of wine have been obtained. 
Prunes and plums grow over an extensive area, and they are mostly used for the manufacture of a national drink called " $t z u i c a . "$

Of the whole arable area, about 34 per cent. is in the hands of farmers owning above $25^{\circ}$ acres, and the rest has been exploited by small farmers; 50 per cent. of the wheat is cultivated by the big farmers, but 80 per cent. of the production of maize is in the hands of the small farmers. The value of the annual agricultural produce for the year 1905, which is considered as a good year, was approximately $36,000,000 l$.

Live Stock.-The live stock and trade connected therewith does not present to-day, for Roumania, the same importance as in the past, the value of the stock being estimated to-day at a little over $18,000,000 l$. On account of the prohibition of export of live stock over the frontiers of Austria-Hungary, this important industry was almost stopped, but a new impetus was given. by granting a concession to an English Syndicate for exporting meat to this country, and much good is expected to be derived to the country by the proper working of this undertaking. With the decrease of this industry, attention has been given to a better utilisation of the available fisheries, and from the exploitation of these the Government now obtains a revenue exceeding roo,oool. per annum, which is increasing.

Forest Exploitation.-One of the important natural resources of Roumania is the extensive forests which cover the whole mountainous region and extend over an area of 6,250,000 acres, and of which $3^{8}$ per cent. belong to the Government, $4 \frac{1}{2}$ per cent. to charitable institutions, a little over $2 \frac{1}{2}$ per cent. to the Crown Lands, and 54 per cent. belong to private owners. The exploitation of the forests is regulated by special legislation. The revenue derived by the State from the exploitation of the forests is constantly increasing, and last year exceeded 260,000l. The commerce and trade with timber is also considerably extending, amounting to over I, 200, 000l. in the year 1905 .

Petroleum Industry.-Another of the most important natural sources of wealth of the country is the oil fields. 'The sub-soil of Roumania is considered very rich in petroleum, but there are not as yet any data available for determining its true value, some estimating it to exceed $300,000,000 l$. The present exploitation, however, is limited to four districts only, of which the district of Prahova produces about 90 per cent. of the total output. Next in order are Bacau, Buzeu, and Dambovitza. The production has grown enormously. In the year 1866 only about 5,370 tons of crude oil were produced, in 1905 it exceeded 600,000 tons, and for the first six months of last year over 380,000 tons have been obtained. The capital invested in the petroleum industry exceeds $6,000,000 l$, of which the largest part has been imported the last year or two, mostly being German, Dutch, French, Italian, American, \&c., and a small proportion English. Apart from the exploitation of the oil fields, there are also a few large refineries being erected, equipped with the most up-to-date apparatus. It is expected from the development of this industry that a large number 
of other auxiliary industries will be created, giving employment $t_{\text {, }}$ a considerable number of the native population. The Roumanian Government owns a large area of petroliferous land, and endeavour's have been made in the last few years to regulate this exploitation : but, unfortunately, no practical solution has as yet been given. The matter is receiving, however, the most earnest attention of the Government and the country generally.

Roumanian Indrustries.-Opinions are divided as to whether it is possible for large industries to be developed in Roumania. The result of the statistical inquiry made in the year 1901-02 showerl, however, that Roumania had then 62, 188 industrial establishments, of which 625 belonged to the big industries, 54,405 to the medium and small ones. The total number of persons employed in this manufacturing industry is represented by 170,000 , of which 40,000 are employed in the big industries and the rest in the medium and smaller ones. The capital involved exceeds $20,000,000 \%$. The situation has, however, been somewhat altered of late.

According to latest statistics (see Bursa, 3rd-16th December, 1906, Dr. N. Paianu's Statistics) the big industrial establishments can be divided in three categories: Firstly, those establishments which benefit from the law of 1887 for the encouragement of home industries, representing over 64 per cent. of the total number: secondly, those industrial establishments, like the flour mills and the breweries, which, on account of the abundance of the raw material they are using, which is found in the country, do not require particular privileges to be granted to them by the Government, forming about 25 per cent.; and thirdly, the industrial establishments owned by the State, forming about Io per cent. of the total number.

The principal centres for the development of industries are the capital, Bucharest, after which follow the district Prahova, with the enormous petroliferous oil fields, Bacau and Neamtzu, with the timber trade, and Covurlui, mostly on account of the port Galatzi on the Danube.

In the first-mentioned category are to be found over r 70 iactories, comprising the saw mills, works connected with the metallurgical industries, glass manufacture, brick and cement. In these factories 10,990 persons are employed, and machinery is used with a rated capacity of over 8,310 h.p. The capital invested is $1,700,000 l$., and the working capital about $1,360,000 l$, the value of the annual production exceeding $\mathrm{I}, 22 \mathrm{29}, 200 \mathrm{l}$.

Next in order is the textile and clothing industry, comprising 49 factories, giving employment to over 5,500 workmen, using over 2,500 h.p. machinery. The capital invested is $561,800 l$., the working capital $375,02 \mathrm{I} l$., and the value of the annual production being $747,294 \%$.

Third in order is the food industry, comprising 35 factories, employing 2,770 workmen and using machinery of 4,6 ro h.p. The capital invested is $\mathrm{r}, 064,189 l$., the working capital $544,625 l$., the value of the annual production being $770,212 \%$.

Next is the paper and paper pulp industry, comprising $2 \mathrm{I}$ factories, giving employment to 2,587 workmen and using machinery of 
4,783 h.p. The invested capital is $537,744 l$., the working capital $226,848 l$. , and the value of the annual production is about $309,556 l$.

Last in this category is the chemical industry, comprising $5 \mathrm{I}$ factories, amongst which 23 are refineries for petroleum, employing over 2,260 workmen, and using machinery of 2,025 h.p. The capital invested is $657,750 l$., and the working capital $77 \mathrm{r}, 600 \mathrm{l}$.; the annual production, which is on the increase, is now exceeding $\mathrm{I}, 024,800 l$.

In the second category are those big industrial concerns which do not require to be encouraged by the State, like the flour mills, spirit refineries, and breweries. The flour-milling industry comprises 86 establishments, employing 2,2.18 workmen, using II,027 h.p. The invested capital is $1,302,080 l$., the working capital $805,040 l$., and the yearly production $3,047,620 l$.

There are 28 spirit refineries employing 1,355 workmen, with r,420 h.p. The capital invested is 5 ro,644l., the working capital $355,280 l$., and the value of the annual production is $209,720 l$. There are 12 breweries employing 858 workmen, and using machinery of r, 426 h.p. The capital invested is $376,800 l$., the working capital r 68,320l., and the annual production r 94,620l.

In the third categor'y the industrial establishments belonging to the State are $5^{2}$ in number, in which $1,943,3{ }^{1}{ }_{5} l$. are invested, employing $9,74^{2}$ persons, and using 9,230 h.p., the annual production exceeding $3,368,960 \%$.

In the aggregate the big industries utilise more than $50,000 \mathrm{~h} . p$. The invested capital exceeds 8,574,3rol., and the working capital $5,702,5 \mathrm{rol}$.

The Government gives considerable encouragement for the establishment and development of industrial concerns, exempting manufacturers from many heavy duties for the importation of raw materials, machinery, \&c., allowing also a great reduction on the rates for railway transport, \&c.

Trade and Commerce of the Country. - The progress made in the trade of the country for the last forty years can very well be gauged by examining the import and export figures which are given for each consecutive five years since 1866 :-

\begin{tabular}{|c|c|c|c|c|c|}
\hline Years. & Imports. & Exports. & Years. & Imports. & Exports. \\
\hline & $£$ & $£$ & & $£$ & $£$ \\
\hline $1866 \ldots . . . .$. & $2,857,170$ & $4,660,014$ & $1891 \ldots . . . . .$. & $17,467,307$ & $10,986,483$ \\
\hline '71.. & $3,317,089$ & $7,107,311$ & & $13,516,917$ & $12,962,266$ \\
\hline '76. & $6,637,340$ & $9,410,251$ & $1901 \ldots \ldots$ & $11,697,430$ & $14,153,235$ \\
\hline '81........ & $10,990,298$ & $8,260,732$ & '05....... & $13,501,519$ & $18,284,055$ \\
\hline ' $86 \ldots \ldots$ & $11,859,894$ & $10,221,890$ & & & \\
\hline
\end{tabular}

It is true that the commercial activity of Roumania for the years 1904-05 has been very great. The value of the exports was the biggest ever registered, the imports gradually decreasing. The value of the exports exceeded the imports in the year $1905 \mathrm{by}$ nearly $4,800,000 l$. 
Roumania imported in the year 1904-05 principally from the following countries : Austria-Hungary contributed with 25 per cent., Germany with 27 per cent., England with 15 per cent., France with 5 per cent., Italy with 4 per cent., Turkey with 4 per cent., Belgium with 2 per cent., and Holland with $1 \frac{1}{2}$ per cent. Fifteen years ago the imports were as follows: Germany stood at the head with 32 per cent., England came second with 26 per cent., AustriaHungary came third with r6 per cent., France with ro per cent., \&c.

In examining the exports, we find that for the year 1905, Belgium took 32 per cent., Holland 18 per cent., Italy ro per cent., Austria-Hungary 9 per cent., Germany $7 \frac{1}{2}$ per cent., England 7 per cent., and France 4 per cent. Comparing these results with those of fifteen years ago, the following change is noticed. In the year 1891, England stood at the head of all the countries with no less than $5^{2}$ per cent., Belgium with 15 per cent., Germany with I I per cent., and Austria-Hungary with 8 per cent. It must, however, be borne in mind that although Belgium heads the list, this is only on account of the fact that Belgium acts as a country of transit, from which the goods are afterwards distributed to Germany, Switzerland, \&c.

The imports of Roumania consist mostly of textiles and all kinds of metals and machinery. The principal products of export are cereals, which represent more than three-quarters of the total value of exports from Roumania.

Railway Extension.-Parallel with the development of the different industries, the means of communication have also been gradually improved and extended. The first railway erected in Roumania was in the year 1869, about 43.5 miles in length, connecting Bucharest with Giurgiu; in 1876 it extended over 597 miles, and to-day the net of railway lines exceed $\mathrm{r}, 975$ miles. The railway belongs to the State, and the cost of same is estimated to exceed $35,400,000 l$. ' There are 338 stations, and about 20,000 to 21 ,, 000 officials and labourers are employed. In the year 1876 the passenger traffic was about 742,000 , in 1905 the number exceeded $5,500,000$. The gross revenue of the railways for the financial year 1904-05 was 2,840,000l.; the expenses being $\mathrm{I}, 500,000 \mathrm{l}$., leaves a net revenue of $492 l$. per kilometre of line. In 1876 the revenue was only $\mathrm{I}_{53} l$. per kilometre.

Ports. - Attached to the railway service there are also large docks erected at the ports at Braila and Galatzi, and new docks are in the course of erection at the port of Constanza on the Black Sea, where, on account of the extended export of petroleum, large petroleum tanks are also being erected by the Government. On account of this port Roumania becomes accessible the whole year round.

Maritime Service.-Among the means of transport belonging to the State, mention must be made of the maritime service, consisting of 10 steamers, of which 5 are used for the transport of goods, running between Braila and Rotterdam, and 5 are used for the transport of passengers and goods, running between Constanza and 
Constantinople, which route is now to be extended to Smyrna, and Alexandria in Egypt. The cost of the steamers is estimated at $600,000 l$.

Postal, Telegraph, and Telephone Extensions.-The postal service, which is maintained by the State, has also received considerable extension. In the year 1904-05 28,400,000 letters, 9,000,000 official stamped envelopes, 26,000,000 post cards, and 40,000,000 packets of printed matter were circulated. The length of the telegraph wires, which in the year 1856 was only 3,790 miles, had increased to $4,4 \mathrm{I} 2$ miles in 1876 , and in the year 1905 exceeded $\mathrm{I} I, 53^{\circ}$ miles. The number of telegrams, internal and foreign, for the same year exceeded 2,250,000. The telephone service is spread all over the country, and direct communication between Bucharest, Braila and Budapest is now established. A submarine cable has been laid connecting Constanza with Constantinople, and this is to be extended to Bagdad and Basorah, forming the shortest route between Berlin and the Orient. A wireless telegraphy station has also been installed at the seaport Constanza.

Revenues and Expenditure.-The economic progress of Roumania stands in very close relation to the State finances. At five-yearly intervals the income and expenditure were as follows :-

\begin{tabular}{|c|c|c|c|c|c|}
\hline Years. & Income. & Expenditure. & Years. & Income. & Expenditure. \\
\hline 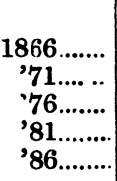 & $\begin{array}{c}f \\
2,362,139 \\
2,640,367 \\
3,245,787 \\
6,171,182 \\
4,979,135\end{array}$ & $\begin{array}{c}£ \\
\mathbf{2 , 7 3 1 , 4 5 7} \\
\mathbf{2 , 9 6 9 , 4 1 0} \\
\mathbf{3 , 9 6 1 , 8 7 0} \\
\mathbf{5 , 1 2 2 , 0 9 7} \\
\mathbf{5 , 1 9 8 , 8 6 5}\end{array}$ & $\begin{array}{r}1891 \ldots . . . . \\
' 96 \ldots . . . . \\
1901 \ldots . . . . \\
' 06 \ldots . . .\end{array}$ & $\begin{array}{r}£ \\
\mathbf{6 , 8 1 4 , 1 5 1} \\
7,923,409 \\
8,101,710 \\
12,321,877\end{array}$ & $\begin{array}{c}£ \\
6,484,674 \\
8,589,619 \\
9,471,734 \\
10,504,016\end{array}$ \\
\hline
\end{tabular}

For the financial year closing on the 30th September, 1906, the income had exceeded the expenditure by $1,800,000 l$., which is the best on record.

In examining the revenues derived from the direct and indirect taxation, and that obtained from the manufacture and sale of tobacco, salt, matches, playing-cards, eigar papers, and gunpowder, which are Government monopolies, the taxation per head of population is estimated at $17 s$. $6 \bar{d}$., or per head of family $3 l$. $18 s .2 \bar{d}$.

Among other sources of Government revenue, apart from the above-mentioned taxations, there may be mentioned those derived from the lease of the Government lands, which are on an increase, and those from the working of the State railways, post, maritime service, \&c.

The financial state of Roumania seems to be greatly improving lately. The budgets for the last five years ending 30 th September, 1906, have been closed with considerable surpluses :

\begin{tabular}{|c|c|c|c|}
\hline Years. & $\begin{array}{c}\text { Surplns. } \\
\mathscr{E} \\
\mathbf{8 4 8}\end{array}$ & 1904-05 & $\begin{array}{l}\text { Surplus. } \\
\stackrel{E}{259,000}\end{array}$ \\
\hline 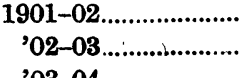 & $\begin{array}{r}848,600 \\
1,193,000\end{array}$ & '05-06, up to & 259,000 \\
\hline
\end{tabular}


which for the five years mentioned exceeds 5,350,00ol. The surplus is, as a rule, used for carrying out works declared of special public utility, and requiring immediate attention. It is quite true that the Roumanian finances have not always been so prosperous, the income being mostly dependent on the results obtained from the harvest, and which is very variable, as can be seen from the consideration of the last eighteen years' budgets. In five years out of the eighteen the budgets were closed with heavy losses, and these years correspond with those of bad harvest. In particular this fact is noticeable for the financial year 1899-1900 when the deficit exceeded by $1,400,000 l$.

The next important items of expense are those of the Ministry of War, which come up to I,800,0ool., representing about I8 per cent. of the total expenditure. It must be remarked that in this year there has been spent another 740,000l. to improve the armament, which money was obtained from the reserve fund derived from the surpluses. Next is the Finance Ministry, spending $1,500,000 l$., representing about 16 per cent. of the total expenditure. For education and religious instruction, as well as religious service, I,040,000l. is spent, representing i I per cent. For extra school requirements and church expenditure there are special funds provided, from which large sums are drawn as necessity arises. In the year 1904-05, 240,00ol. was separately spent from the Church fund. The Home Office service costs $800,000 l$., the maintenance of school buildings and other dependencies of the Ministry of Public Works requires an expenditure of r 80,000l., the Ministry of Justice 215,200l., the Ministry of Agriculture, Commerce, and Industry, r69,000l., and the Foreign Office $7 \mathrm{I}, 440 \mathrm{l}$. These items naturally vary yearly, but on the whole represents a fair average of distribution of expenditure.

National Debt.- In order to achieve the great progress referred above, the national debt had to be increased. In the following table figures are given showing for the ten-yearly periods the increase of the debt, and the rate at which the repayment of annuities has to be made :-

\begin{tabular}{|c|c|c|c|c|}
\hline \multirow{2}{*}{ Years. } & \multirow{2}{*}{ National Debt. } & \multicolumn{3}{|c|}{ Annuities. } \\
\hline & & Interest on Loan. & Amortisation. & Total. \\
\hline $\begin{array}{r}1866 \ldots \ldots . . . \\
\quad 76 \ldots \ldots . . \\
' 86 \ldots \ldots . . \\
' 96 \ldots \ldots . . . \\
1906 \ldots \ldots . . .\end{array}$ & $\begin{array}{c}£ \\
3,210,000 \\
20,621,000 \\
28,960,000 \\
47,320,000 \\
\mathbf{5 7 , 7 4 2 , 8 0 0}\end{array}$ & $\begin{array}{c}£ \\
380,000 \\
1,054,000 \\
1,773,000 \\
2,640,000 \\
2,446,200\end{array}$ & $\begin{array}{c}£ \\
69,000 \\
560,000 \\
400,000 \\
440,000 \\
869,800\end{array}$ & $\begin{array}{c}£ \\
449,000 \\
1,614,000 \\
2,173,000 \\
3,080,000 \\
3,316,000\end{array}$ \\
\hline
\end{tabular}

Last year's repayment of $3,316,000 l$. represents about $3^{8}$ per cent. of the total budget expenditure.

The interest paid on the capital borrowed varied at different periods, exceeding in some cases even 8 per cent.; but now the greatest part of the loan has been converted into "rentes" of 4 per 
cent., with the exception of only 13 per cent. of the total debt, which is still rated at 5 per cent. interest.

The national debt has to be extinguished in a very short period, and in some of the years it will be extraordinarily heavy. In forty years, according to the present arrangement, over $50,000,000 l$. will have to be repaid. The present Finance Minister, Mr. Tache Ionescu, is therefore endeavouring to put the finances of the country on a sounder basis.

It may be interesting to know that there are several financial institutions in Roumania, among which, in the first place, may be mentioned the National Bank, an institution placed under the control of the Government, founded twenty-five years ago with a capital of only $4 \mathrm{r} 8,000 \mathrm{l}$; n now it has a reserve in gold exceeding $4, \infty \circ 0,000 l$., which represents 33 per cent. of the nominal value of the issued papers. There are other important financial institutions like the "Credit Rural," the "Credit Urban," \&c., and also other banking houses, amongst which the "Bank of Roumania, Ltd.," may" be mentioned as an English institution.

There is a growing tendency to develop industries in Roumania, for which purpose foreign capital and experience was, and is still, needed to be introduced. Special mining laws had to be framed for safeguarding the interest of the would-be investors, and a patent law was passed last year for protecting inventors. Amongst other reforms necessary the Roumanian Government ought to settle the position of its large Jewish population, which will have far-reaching consequence for the development of the trade and commerce of the country. With the administration of the law more independent of political influences, Roumania will be able to show continuous progress in the future.

For most of the data contained in this article I am indebted to Dr. L. Colescu, the head of the Statistical Department of the Ministry of Domains, who, it may be mentioned, has also prepared two figurative tables showing at a glance the progress made during the forty years, in ten-yearly intervals.

\section{V.-CORRESPONDENCE.}

To the Editors of the Journal.

SiRs,-The result arrived at in the paper by Mr. Harris and the Rev. Kenneth Lake, on the "Estimates of the Realisable Wealth of the United Kingdom, based mostly on the Estate Duty Returns," 1 is so erroneous, in consequence of the wrong principle adopted with the Estate Duty Returns, that some notice upon the subject seems to be needful.

${ }^{1}$ Journal, vol. lxix, p. 709 sqq.

VOL. LXX. PART I. 